\title{
COMUNICAÇÃO DIGITAL E TRADIÇÃo DO VATICANO: DA PROPAGANDA AO "JORNALISMO DE INFLUÊNCIA"
}

\author{
- MÁRCIA MARAT GRILO ${ }^{1}$ \\ - ANGELA ANZELMO ${ }^{2}$ \\ - DAVID DOUYÈRE ${ }^{3}$
}

1 Instituto Politécnico de Portalegre - Escola Superior de Educação e Ciências Sociais, Portugal/SIC. Lab Méditerranée - Université Côte d'Azur, France. Portalegre Polytechnic Institute - School of Education and Social Sciences, Portugal / SIC. Lab Méditerranée - Université Côte d'Azur, France. E-mail: marciagrilo@ipportalegre.pt. 2 CeReS - Université de Limoges, France/Coris - Università degli studi Roma Sapienza, Italia. E-mail: angelanzlm@gmail.com.

3 Prim - Université de Tours, France. E-mail: david.douyere@gmail.com.

Recebido em: 07/01/2019

Aprovado em: $23 / 08 / 2019$

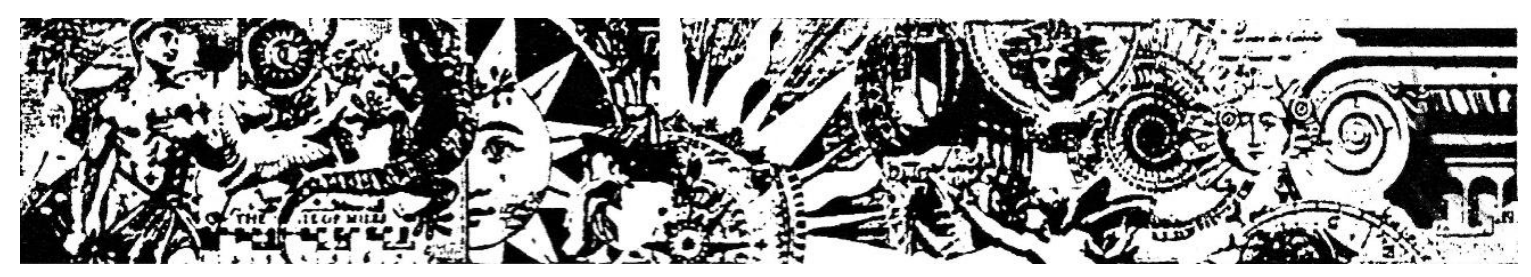

Resumo: Este artigo explora a forma como a instituição do Vaticano tem utilizado os seus próprios meios de comunicação ao longo da história e após a institucionalização da Secretaria para a Comunicação (junho de 2015) criada especialmente para comunicar através do meio digital (websites, redes sociais). Estudando, por um lado, os antigos sites do Osservatore Romano (imprensa escrita do Vaticano) (http://www.osservatoreromano.va/), da Radio Vaticana (http://fr.radiovaticana.va/) e do Centro Televisivo do Vaticano (CTV) e, por outro lado, o novo portal Vatican News (http://www.vaticannews.va/) on-line desde janeiro de 2018, pretende-se defender a hipótese segundo a qual a comunicação institucional do Vaticano se insere num chamado jornalismo de influência ou constitui uma forma de mídia das fontes no sentido proposto por Francisco Sant'Anna $(2006,2007)$. Como tem evoluído essa comunicação institucional e corporativa ao longo dos tempos e até muito recentemente com a abertura do novo portal web Vatican News? Inicialmente propomos, numa perspectiva genealógica, uma revisão histórica dos meios de comunicação do Vaticano e da sua utilização para tentar perceber de que forma a reflexão cristã católica se modifica a partir da utilização da Internet. De facto, o atual desafio colocado pelas tecnologias informatizadas permite à instituição do Vaticano procurar entrar no debate público em vez de permanecer isolada em termos de comunicação, num contexto em que ela é alvo de intensos ataques e críticas, acompanhados de um certo eco mediático.

Palavras-chave: ciências da informação e da comunicação; Vaticano; média de massa; semiótica; tecnologias informatizadas. 


\title{
THE DIGITAL COMMUNICATION AND VATICAN TRADITION FROM PROPAGANDA TO "INFLUENTIAL JOURNALISM"
}

\begin{abstract}
This paper explores how the Vatican institution has used its own media throughout history and after the institutionalization of the Secretariat for Communication (June 2015) created especially to communicate through the digital media (websites, social networks). Studying, on the one hand, the old sites of Osservatore Romano (Vatican press) (http://www.osservatoreromano.va/), Vatican Radio (http://radiovaticana.va/) and the Vatican Television Center (CTV) and, on the other hand, the new Vatican News website (http://www.vaticannews.va/) on-line since January 2018, aims to defend the hypothesis according to which the institutional communication of the Vatican is inserted in the so-called influence journalism or constitutes a form of media of the sources in the sense proposed by Francisco Sant'Anna $(2006,2007)$. In what way has this institutional and corporate communication evolved over time and, until very recently, with the opening of the new Vatican News website? From a genealogical perspective, we propose initially a historical review of the Vatican media and its use to try to understand how Catholic Christian reflection changes from the use of the Internet. Indeed, the challenge set by computerized technologies enables the Vatican institution to enter into the public debate rather than to remain isolated in terms of communication, in a context where it is subject of intense attacks and criticism, which are provided of a media echo.
\end{abstract}

Keywords: information and communication sciences; Vatican; mass media; semiotics; digital technologies.

\section{COMMUNICATION NUMÉRIQUE ET TRADITION VATICANE DE LA PROPAGANDE AU «JOURNALISME D'INFLUENCE»}

Résumé: Cet article se propose d'explorer comment l'institution vaticane utilise ses médias au fil de I'histoire et après l'institutionnalisation du Secrétariat pour la communication (juin 2015) créé notamment pour communiquer via le numérique (sites web, réseaux sociaux). En étudiant d'une part les anciens sites web de l'Osservatore Romano (presse écrite du Vatican) (http://www.osservatoreromano.va/), de Radio Vatican (http://fr.radiovaticana.va/) et du Centre de télévision du Vatican (CTV), et d'autre part, le nouveau portail de Vatican news (http://www.vaticannews.va/) en ligne depuis janvier 2018, nous entendons défendre l'hypothèse selon laquelle la communication institutionnelle du Vatican s'insère dans un journalisme d'influence ou constitue une forme de média de sources au sens de Francisco Sant'Anna (2006 ; 2007). Comment cette communication institutionnelle et corporative évolue-t-elle au fil du temps et jusqu'à très récemment avec l'ouverture du nouveau portail Web Vatican news ? Nous proposerons au préalable, dans une perspective généalogique, un examen historique des médias du Vatican et de leur utilisation pour tenter de voir en quoi la réflexion chrétienne catholique change au moyen de l'outil qu'est Internet. En effet, le défi posé par les technologies informatisées permet à l'institution vaticane d'avoir le sentiment d'entrer dans le débat public plutôt que celui de demeurer isolée en termes de communication, dans un contexte où elle connaît de vives attaques et critiques, pourvues d'un certain écho médiatique.

Mots-clés: sciences de l'information-communication ; Vatican ; mass media ; sémiotique ; technologies informatisées. 


\section{Introdução}

A comunicação do Vaticano renova-se e recentra-se hoje, procurando responder às críticas dirigidas à Igreja Católica, e assegurar a sua presença na esfera pública. A comunicação digital desempenha um grande papel nesse recentramento. No entanto, ela é apenas a última etapa de um processo muito antigo de agregação de dispositivos de comunicação ao serviço de uma difusão de sentido que visa afirmar o imaginário cristão, e as suas próprias mitologias, pela proclamação do texto e da imagem construindo sentido. Porque a comunicação cria um universo, faz existir, ao mesmo tempo em que ela "anuncia". A comunicação e o cristianismo são inseparáveis (DOUYÈRE et al., 2016): este origina-se na comunicação (do próprio deus cristão, pela teologia do Verbo). O que é dito e apresentado online inscreve-se numa longa tradição de mobilização mediática (PINTO DE OLIVEIRA, 1968). O que mudou, em várias sociedades (fora do Vaticano, talvez), é que a Igreja Católica já não domina o espaço público (DAGENAIS, 1996); ela deve portanto encontrar novas maneiras para fazer ouvir a sua mensagem, mesmo que ela própria se torne media e fonte, quando o prisma mediático se torna particularmente crítico e deformante. É esse caminho e essa reversão comunicacional que nós propomos reler aqui conjuntamente.

\section{Quadro teórico e corpus}

Primeiramente, focalizámo-nos no estudo dos usos das tecnologias da informação e da comunicação (TIC) do Vaticano. A nossa principal metodologia consistiu, portanto, em descrever a utilização que os atores do Vaticano fazem das tecnologias, por um lado, e o seu público, por outro lado. Examinando de forma global os meios de comunicação institucionais (imprensa, televisão e internet), ou seja, os discursos transmitidos pelo suplemento, Donne, Chiesa, Mondo do Osservatore Romano (imprensa escrita), pelo antigo site do Centro Televisivo do Vaticano, pelo site da Rádio Vaticana e pelo novo site Vatican News, privilegiámos um eixo semióticocomunicacional na medida em que esses discursos apresentam um valor simultaneamente no plano comunicacional e no plano manipulatório, visando uma ação, um "fazer" do público, especialmente nas plataformas das redes sociais. 0 nosso estudo centrado no processo de mediatização consiste, portanto, em focalizar a nossa atenção na "circulação, na metamorfose, na transformação dos textos e dos saberes", e tentar definir, analisar essa circulação, através de uma abordagem que visa apreender as práticas enquanto fenómeno de significação (SOUCHIER et al., 2003). Trata-se de examinar como o Vaticano trabalha os seus discursos de acordo com a doxa 
(opiniões comuns, preconceitos e pressuposições) (ANZELMO, 2018a) para entrar em debates mediáticos de grande amplitude e, assim, alcançar cada vez mais um público diversificado feito de crentes católicos, de não-crentes e de pessoas em busca de "espiritualidade" (DUFOUR, 2016).

\section{A Comunicação mediática do Vaticano e o "jornalismo de influência": que evoluções?}

O nosso trabalho procura questionar as principais evoluções na comunicação mediática do Vaticano. Para isso, tentaremos compreender como a instituição do Vaticano se tem apropriado, ao longo dos tempos, dos principais media modernos. Também propomos refletir sobre a forma como a comunicação institucional da Sé Apostólica pode inscrever-se no fenómeno chamado de "jornalismo de influência", no sentido proposto por Francisco Sant'Anna (2006; 2007). Trata-se, em seguida, de nos interrogarmos sobre as principais evoluções teológicas desta comunicação, considerada como uma forma de "jornalismo de influência" no contexto digital e de sublinhar o papel que os meios de comunicação do Vaticano desempenham enquanto "difusores corporativos" (SANT'ANNA, 2006).

\section{Evoluções da comunicação do Vaticano}

A noção de comunicação e de suportes atravessou a história religiosa cristã (DOUYĖRE, 2010a). É importante constatar que a relação com a escrita e as Escrituras, a liturgia como produção de signos "celebrando" Deus, a formação na arte da fala (pregação), a própria noção de "Propaganda da fé" (Gregório XV, Inscrutabiliti divinae providentiae, 1622) e de evangelização e, claro, o uso dos media (da tipografia às redes sociais, passando pela rádio e a televisão, e os grupos de imprensa, desde o século XIX...) apresentam elementos de uma reflexão cristã. A cultura cristã tendo, talvez, constituído, através desses elementos e dessas práticas, uma matriz da comunicação ocidental moderna (DOUYĖRE, 2010a). Esta reflexão sobre a comunicação revela-se particularmente católica e o cristianismo pode surgir como um sistema total de comunicação (PACE, 2011).

O cristianismo é, por excelência, a religião da relação, é por esta razão que a comunicação detém nela uma dimensão central, o aspeto "relacional" está no cerne da comunicação cristã para a qual a troca e o diálogo constituem valores principais. No entanto, de um ponto de vista cristão, a "comunicação da Igreja" difere da "comunicação do mundo" (LEVALOIS, 2012). A primeira dizse baseada na comunhão, o que contrasta, por esse motivo, com a percepção cristã da 
comunicação do mundo moderno, pensada para procurar construir relações de "força" e para instalar relações de dominação (as quais, no entanto, não se pode ignorar que existem nas Igrejas). Isto conduziu as Igrejas (nomeadamente as cristãs) a dispensar um controle - não absoluto - dos diferentes vetores de comunicação onde os media Ihes escapam, difundindo frequentemente um pensamento em contradição com o ensino cristão (LEVALOIS, 2012, p. 47). Apesar disso, observa-se que:

Um importante esforço em direção aos media tem sido feito desde há várias décadas. Não apenas para melhor os compreender, manter relações de cortesia, garantir uma boa transmissão de informações, mas também com vista a edificar polos mediáticos das Igrejas com o intuito de facilitar a difusão das suas informações. (LEVALOIS, 2012, p. 48).

No que respeita à reflexão e às práticas adotadas em relação aos meios de comunicação social, pode constatar-se, no caso da Igreja Católica, uma antiga e grande atenção dada à questão (LEVALOIS, 2012). De fato, o número, a importância e o volume de textos/documentos produzidos sobre os mídia (BARAGLI, 1973, MEDIATHEC, 1990) são bastante consideráveis (especialmente depois do Concílio Vaticano I/ que realizou de 1962 a 1965, - bem como a organização de eventos emblemáticos, nomeadamente o Dia Mundial das Comunicações Sociais, que se realiza todos os anos desde 1967). Além disso, um olhar atento sobre a evolução recente da Igreja Católica permite-nos compreender a elaboração de uma doutrina religiosa sobre os meios de comunicação e o convite regular para uma prática mediática (DOUYĖRE, 2017).

\section{De propaganda fide}

Como verdade recebida e comunicada, uma religião convida muitas vezes a participar, através da propaganda (esse ancestral moderno da comunicação que visava a "propagação" da fé) e da comunicação prosélita, incitativa (DOUYÈRE, 2017). Aliás, as origens da palavra "Propaganda", vindas do latim "propagere" (propagar) e indicando um tipo de discurso com um objetivo persuasivo, encontram-se ligadas à Igreja Católica, e que permite propagar a fé. O papa Gregório XV, retomando um projeto de Gregório XIII concebido por volta de 1580, instituiu, através da bula papal Inscrutabili Divinae, a Congregação para a Propagação da Fé - De propaganda fide - em 1622. Esta congregação tinha o objetivo hegemónico de difundir a fé católica de todos os meios possíveis e era um dos pilares da Contrarreforma. Na prática, De propaganda fide, identificada oficiosamente como Propaganda, era, portanto, a instituição encarregada de organizar 
toda a atividade missionária da Igreja. Esta congregação é chamada desde 1988 de "Congregação para a Evangelização dos Povos4."

\section{Da tipografia à imprensa escrita}

Em meados do século XV, a corporação clerical acolheu a invenção da tipografia por Gutenberg (PINTO DE OLIVEIRA, 1992), vendo nela um simples suporte (técnico) suplementar, sem se aperceber que ela colocava em jogo uma nova relação social (DEBRAY, 2000, p. 47) tendo profundas consequências para a história da humanidade em geral e para o cristianismo em particular. Ora, esta invenção foi um dos fatores que contribuíram decisivamente para 0 desenvolvimento da Reforma Protestante, sendo também usada pela Igreja Católica, particularmente na luta contra "a alegada religião reformada".

A utilização importante da tipografia durante o período da Reforma Católica é saudada pela proclamação de São Francisco de Sales como patrono dos jornalistas ${ }^{5}$. As folhas e os placards que ele distribuía quando pregava em 1594 junto dos protestantes de Chablais podem ser vistos como uma forma pioneira de "jornalismo". Essas publicações digamos, embora não estivessem sujeitas a uma periodicidade, forneciam ideias e orientações que suscitavam discussões. Portanto, elas veiculavam informações fazendo parte dos primeiros "jornais" católicos do mundo.

No entanto, a Igreja Católica manteve por muito tempo uma certa postura de "diabolização" face à imprensa escrita. Na encíclica Mirari vos de 1832, Gregório XVI escreveu que a liberdade de imprensa é "a mais nefasta" das liberdades, "uma liberdade execrável", acrescentava ele, "para a qual nunca se experimentará horror suficiente". Ainda mais simbólico, no famoso Syllabus escrito em 1864 por Pio IX, a liberdade de imprensa ainda ocupa um bom lugar na lista dos "grandes erros" do mundo moderno, ao lado do socialismo, do racionalismo, do relativismo etc. É a imprensa, diz este papa, que deprava a moral das pessoas boas e as desvia nos seus valores e na sua fé6.

\footnotetext{
${ }^{4}$ A Congregação para a Evangelização dos Povos (Congregatio pro Gentium Evangelizatione) é um dicastério departamento do governo da Igreja Católica - da Cúria Romana, que lida com questões relativas à difusão da fé católica em todo o mundo.

5 Em 1923, Pio XI proclamou-o como santo padroeiro dos escritores e dos jornalistas, por causa do seu recurso à tipografia, porque Francisco de Sales usou extensivamente panfletos e livros para apoiá-lo na direção espiritual e nos seus esforços para converter os calvinistas da sua diocese.

${ }^{6} \mathrm{H}$. Tincq e G. Défois, Les médias et l'Eglise. Evangélisation et information : le conflit de deux paroles, CFPJ, Paris, 1997, p. 108.
} 
Só a partir da segunda metade do século XIX a Igreja Católica investiu verdadeiramente na impressa escrita. Durante cerca de um século até 1950, conceber jornais significava, para os católicos, conceber periódicos de opinião. Tratava-se de fazer com que a voz, ou as vozes dos católicos, fossem ouvidas no fórum das ideias e das ideologias que se disputavam, o que se chama hoje as "escolhas de sociedade"7. Desde o início, o jornalista católico é simplesmente um portavoz, representante de uma instituição cujos princípios e a moral ele deve defender. Duas razões explicam, segundo J. Broucker (1992), o investimento da Igreja Católica na imprensa. A primeira diz respeito às necessidades de informações e de comunicação próprias à "sociedade" católica e aos seus vários grupos. A segunda é a de expressar e fazer ouvir a voz dos católicos nos debates da atualidade ${ }^{8}$. A Igreja Católica é chamada a comunicar com o mundo que a rodeia, ao mesmo tempo, ela tem também necessidade de fazer circular a informação no seu próprio seio. Gradualmente, a partir de meados do século XIX até aos nossos dias, a instituição mostra uma nova visão da imprensa, de uma doutrina católica do jornalismo e das suas missões, que resume bem a expressão "apostolado da imprensa" - sob esta expressão entende-se a missão que a Igreja Católica atribui às suas próprias publicações e aos seus atores: jornalistas e editores.

\section{Osservatore Romano e Radio Vaticano}

Fundado em 1861, o Osservatore Romano é um jornal publicado na Cidade do Vaticano. Cobre todas as atividades públicas do papa e publica editoriais escritos por importantes membros do clero da Igreja Católica. Sai todos os dias (exceto ao domingo) ao início da tarde e é datado do dia seguinte. Difunde, entre outros, o suplemento mensal Donna, Chiesa, Mondo. O jornal é uma das três principais fontes oficiais para a difusão da atualidade do Vaticano, juntamente com a Rádio Vaticano e o Centro de Televisivo do Vaticano (agora rebatizado como Vatican Media).

Apesar de uma tomada de consciência um pouco tardia das vantagens e possibilidades oferecidas pelos mídia, Pio XI inaugura a Rádio Vaticana com a primeira mensagem radiofónica, que exalta a "admirável obra de Marconi9" (a rádio), em 12 de fevereiro de 193110. Os programas passam rapidamente a ser realizados em nove idiomas: sendo desde o seu nascimento, uma rádio poliglota. Durante a Segunda Guerra Mundial e depois a Guerra Fria, ela tornou-se um vetor

\footnotetext{
7 J. de Broucker, La presse catholique en France : état des lieux et des questions, Le Centurion, Paris, 1992, p. 31.

8 J. de Broucker, Op. Cit., p. 33.

9 No dia seguinte à criação do Estado do Vaticano (1929), Pio XI confiou ao engenheiro Marconi e aos jesuítas a criação de uma estação de rádio dentro do novo Estado.

10 «The Founding Radio», disponível em: http://www.vatican.va/news_services/radio/multimedia/storia_ing.html, consultado a 15 de abril de 2018 . 
precioso da liberdade de expressão e da liberdade religiosa em face ao nazismo e ao comunismo. A guerra acelera seu desenvolvimento, ela transmite em 1948 as emissões em 19 línguas ${ }^{11 .}$ Durante os anos do pós-guerra, a Rádio Vaticano expande-se consideravelmente: outras línguas vêm enriquecer as emissões e a necessidade de ter emissores mais potentes ${ }^{12}$ surge pouco a pouco. Graças ao seu multilinguismo e à capacidade de ser retransmitida em todo o mundo, a Rádio Vaticana contribuiu largamente para destacar as posições do Vaticano desde a sua criação. Atualmente, ela é transmitida em 5 canais e em 40 idiomas. 0 canal I oferece as suas emissões regulares em italiano, em inglês e em francês; o canal II transmite os seus programas em português, espanhol e alemão ${ }^{13}$. Graças aos seus contatos eclesiais e jornalísticos em vários países, a Rádio Vaticana permanece no centro de uma rede de informações muito rica ao serviço do papa e da Igreja Católica.

\section{Concílio Vaticano II e o conceito de "Comunicação Social"}

Vaticano II (1962-1965) constitui o primeiro concílio "mediatizado" da história do catolicismo. O seu desenvolvimento situa-se no período de crescimento eufórico dos meios de comunicação audiovisuais que contribuíram para popularizar grandes figuras da época, incluindo João XXIII e Paulo VI. A imprensa, a rádio, a televisão, o cinema, o livro são, então, mobilizados para dar a conhecer ao mundo inteiro os trabalhos do XXI conselho católico e este evento foi coberto por centenas de jornalistas do mundo inteiro. Pela primeira vez, os homens da Igreja preocupam-se com a informação e, como nunca anteriormente, a informação interessa-se pelos homens da Igreja (TINCQ e DÉFOIS, 1997, p. 110). Os meios de comunicação deram uma dimensão católica, isto é, universal ao concílio, envolvendo o mundo inteiro no seu desenvolvimento. Este evento constituiu um passo decisivo na história do encontro da Igreja Católica e dos media. Este exprime-se, em particular, através do decreto do concílio Vaticano II Inter Mirifica de 1963, mas, principalmente, através de um documento posterior, a instrução pastoral Communion et Progrès de 1971, redigida sob mandado especial do concílio.

\footnotetext{
11 Ela lança apelos para a busca de civis e soldados desaparecidos ou difunde mensagens das suas famílias aos prisioneiros.

12 Em 1954 inicia-se a construção do centro emissor de Santa Maria di Galeria, inaugurado por Pio XII em 27 de outubro de 1957. Em 1958, ano da eleição de João XXIII, foram construídos novos estúdios e escritórios.

13 Para o resto da Europa e para a América, a Rádio Vaticano oferece transmissões nos seguintes idiomas: croata, checo, eslovaco, polonês, húngaro, esloveno, árabe, esperanto, armênio, russo, ucraniano, bielorrusso, lituano, letão, albanês, búlgaro e romeno. Os programas para a Ásia e a África são oferecidos em árabe, hindi, tâmil, malaiala, suaíli, amárico, francês, inglês, português, espanhol, chinês, japonês, vietnamita e somali. 
Vaticano II marca a irrupção da Igreja Católica na grande cena mediática (TINCQ ET DEFOIS, 1997, p.110), pois é a partir deste momento que a ela se mobiliza fortemente no campo da comunicação, adotando uma posição única para promover a utilização dos media em favor da evangelização. Convém sublinhar, aliás, que a noção de "comunicação social" constitui, de acordo com a obra de J. Dèveze (DOUYÈRE 2010b) "uma criação conceptual da Igreja Católica". Comparando a encíclica Pio XII sobre cinema, rádio e televisão Miranda Prorsus (1957) e o decreto conciliar Inter Mirifica, promulgado por Paulo VI (1963), constata-se que as palavras que evocam a difusão e a transmissão desaparecem em benefício daquelas que evocam a comunicação. Essa mudança de vocabulário mostra que uma das vias da atualização da apresentação da doutrina católica consiste em substituir o discurso da transmissão e da difusão pelo discurso da comunicação em geral e da comunicação social em particular. A palavra "meio" é preferível a "técnico"; "comunicação" a "transmissão"; "social" a "coletivo" ou "de massa" (DOUYĖRE, 2010b).

\section{0 decreto conciliar Inter Mirifica}

Percebendo a importância do setor de comunicação, a Igreja Católica criou instituições mediáticas a partir das duas primeiras décadas do século $X X^{14}$. 0 evento mais emblemático a ser sublinhado, além da criação de um gabinete de imprensa da Santa Sé em 1960 para o concílio Vaticano II, é efetivamente, a publicação, em 1963, do texto Inter Mirifica sobre os meios de comunicação social. Este pequeno texto marca uma importante etapa na reflexão sobre a responsabilidade social dos mídia, tomado no sentido mais amplo e mostra a importância que a Igreja Católica atribui aos mídia. Esta define aí a sua posição em relação a eles no que diz respeito à sua missão de pregar o Evangelho e enfatiza o seu dever de esclarecer os homens na sua utilização dos mídia. Entre as recomendações, o concílio institui um dia por ano, dedicado aos meios de comunicação social15:

Este documento reconhece 0 direito à informação e pretende desenvolver uma imprensa genuinamente católica. Em 1964 foi criada uma Comissão Pontifícia dos meios de comunicação social. [...] Em 1967 teve lugar o primeiro Dia Mundial das Comunicações Sociais. (CHARENTENAY, 2011, p. 106).

\footnotetext{
${ }^{14}$ Segundo P. Charentenay, (2011), duas instituições foram criadas em 1928: a OIC - Organização Católica Internacional do Cinema, e a UNDA - Associação Católica Internacional para a Rádio (à qual foi acrescentada a televisão). Em 2001, essas duas organizações fundiram-se para formar a SIGNIS - a Associação Católica Mundial para Comunicação, que tem escritórios em 140 países ao redor do mundo. No próprio Vaticano, tudo começa em 1931 com a inauguração da Rádio -Vaticano por Pio XI, rádio que se torna mundial em 1957, pp. 104-105.

15 O Dia Mundial das Comunicações Sociais é um evento importante ao longo do qual é atualizado em que a cada ano, num discurso pontifício, o discurso comunicacional da Igreja Católica (agora voltada para o digital). 
Neste decreto, o termo "meios de comunicação social" é usado pela Igreja Católica, que encoraja a utilizá-los para tornar presente a palavra cristã numa sociedade em que, segundo ela, os media seculares dominam. Como as técnicas de progresso evocadas noutros textos do concílio, esses meios são abordados com espanto, admiração e confiança: basta compreender o que significa o título Inter Mirifica: "Entre as maravilhosas descobertas". A Igreja Católica, portanto, retém o termo "comunicação" para manifestar o sentido de transmissão entre os homens e da partilha que implica a participação ativa, não apenas do transmissor, mas também do recetor. 0 adjetivo "social" foi escolhido, por um lado, para descartar, na época, o termo "massa" percebido como tendo um tom pejorativo de irresponsabilidade e despersonalização; mas também para significar que a comunicação é um dos principais fatores na indispensável interdependência entre o desenvolvimento da pessoa humana e o desenvolvimento da própria sociedade. Assim, é com Inter Mirifica que se forma a noção de "comunicação social" que, retomando o adjetivo da doutrina social da Igreja, nasceu para contrariar o socialismo e o comunismo e para dar uma ancoragem social à ação da Igreja Católica, vem qualificar os mídia de massa emergentes numa perspetiva mais personalista. O termo "propaganda" que havia surgido no século XVII, para designar a propagação da fé e os meios a ela relacionados, também desaparece, muito conotado com uma dimensão manipuladora, fascista e assassina (DOUYÈRE, 2015, p. 230). Ao insistir na boa utilização dos mídia, desempenhando o papel de "consciência" do mundo no campo mediático, a Igreja convida-se ao debate, coloca-se na praça pública e presta-se à discussão. Mas trata-se realmente, interroga-se Frédéric Antoine (2003) de um "diálogo" no qual a Igreja Católica estaria pronta para escutar? Ou ela quer apenas ser escutada? A sua posição não é ainda um tanto proeminente? Vaticano // teria trazido a virtude da "discussão", da "escuta" e da "abertura". A Igreja "especialista em humanidade" tornar-se-ia finalmente uma "Igreja em diálogo com o mundo". Trata-se sobretudo de um reposicionamento eclesial no espaço social e mediático:

A expressão 'comunicação social' significa para a Igreja Católica que a comunicação faz sociedade, e reciprocamente, e que os mídia se dirigem a pessoas, criadoras e não simplesmente passivas, não a uma massa. [...]. A expressão engloba e designa, sobretudo, a estratégia de apropriação mediática da Igreja, que amplia e não faz desaparecer a noção de propaganda, que se torna 'evangelização'. A 'comunicação social' é, portanto, esse campo no qual a lgreja vê o surgimento de técnicas de comunicação de massa na sociedade e que ela entende não deixar muito tempo estranha ao seu conhecimento. (DOUYĖRE, 2010b, p. 73 \&83). 


\section{Communio et Progressio: uma instrução pastoral decisiva}

Graças ao Papa Paulo VI, um outro passo em frente é dado nesta tomada de consciência dos desafios da comunicação. Na instrução pastoral Communio et Progressio ${ }^{16}$, publicada em 1971 sobre o mandato conciliar, e com uma reflexão renovada, a Igreja Católica passa de uma concessão utilitarista dos media - meios de combater um inimigo e transmitir a boa palavra - a uma atenção dada à informação por ela mesma, aos profissionais que a realizam e à necessidade de a instituição religiosa encontrar o seu lugar nas novas tecnologias e nos mídia do futuro. 0 tom moralista desaparece. A perspectiva é ampliada e o poder de ressonância dos meios de comunicação é enfatizado positivamente (TINCQ e DÉFOIS, 1997, p.111).

$\mathrm{Na}$ verdade, depois do concílio, novos passos no que respeita à reflexão sobre a importância dos mídia foram dados no seio da Igreja Católica, particularmente com este texto fundador ${ }^{17}$. Ele centra-se nos meios de comunicação como fatores de progresso humano, como 0 seu título indica.

\section{João Paulo II e os media}

As práticas da Igreja Católica promovidas pelo Papa João Paulo II que, desde sua eleição em 1978, utilizou deliberadamente as suas viagens como eventos mediáticos (DAYAN, 1990, 2005), demonstram que a Igreja Católica soube através da inovação relativa à promoção de eventos, baseados no ajuntamento em massa e da vedetização, mobilizar os mídia e as multidões (MARCHESSAULT, 2002). De facto, para o papa polonês, "o primeiro areópago dos tempos modernos é o mundo da comunicação", que dá unidade à humanidade fazendo dela, diz-se, uma "grande aldeia", como num eco McLuhaniano. Segundo ele, a comunicação não "serve" apenas para transmitir uma mensagem. Ela torna-se quase a própria "mensagem", como disse Marshall McLuhan (TINCQ e DEFOIS, 1997, p.112), esse teórico dos mídia que desempenhou, após a sua conversão ao catolicismo, um papel oficial na elaboração da doutrina da Igreja Católica sobre a comunicação, como conselheiro do Vaticano (com o decreto Inter mirifica institui-se um conselho pontifício, do qual ele será em seguida consultor).

\footnotetext{
16 Instrução pastoral para a aplicação do Decreto do Concílio Ecumênico Vaticano II, Inter Mirifica, elaborado pela Pontifícia Comissão dos Meios de Comunicação Social e publicado em 23 de maio de 1971.

17 Communio et Progressio concretiza certas declarações de Inter Mirifica e dá orientações para as Igrejas Católicas locais em todo o mundo. 
João Paulo II coloca decididamente a instituição no caminho dos media e a primeira condição é a de conhecer a sua cultura, a formação torna-se, portanto, um leit motiv. Assim, a Igreja lança-se nessa tarefa, com a realização de sessões de formação, de conferências, de dias de estudo, etc. Pode, portanto, afirmar-se que com João Paulo II, a Igreja Católica conhece um ponto de viragem e que a comunicação é agora parte da missão e da pastoral da Igreja. Além disso, ela também reconhece que o uso das técnicas e das tecnologias da comunicação contemporânea faz parte integrante da sua missão específica no terceiro milénio. Charentenay (2011) assinala precisamente o início de uma nova era com João Paulo II, sabendo aproveitar as novas capacidades fornecidas pelos meios de comunicação: "um novo período em que o pontífice é um ator de primeira ordem no cenário da mediático. [...] Ele joga o jogo da informação e da comunicação". Entretanto, a Igreja Católica tem procurado um acesso mais direto aos meios de comunicação, ocupando a cena pública, ela tem desenvolvido estratégias mediáticas, apoiandose em grandes encontros como a Jornadas Mundiais da Juventude, por exemplo.

\section{Centro Televisivo do Vaticano}

Vatican Media, conhecido até 2017 sob o nome de Centro de Televisivo do Vaticano, é um canal de televisão criado em 1983 e tornado um órgão ligado à instituição do Vaticano. 0 objetivo principal é contribuir para a propagação universal do Evangelho, documentando através de imagens de televisão, o ministério pastoral do Papa e as atividades da Sé Apostólica. Os principais serviços prestados pelo Vatican Media são as emissões de televisão em direto, a produção e os arquivos de vídeo. Vatican Media filma cerca de 130 eventos por ano no Vaticano (audiências gerais, outros eventos ou celebrações), aos quais é preciso adicionar os programas por ocasião das viagens apostólicas em Itália e no mundo. As emissões em direto são transmitidas por outras redes de televisão católicas. A pedido das várias redes de televisão no mundo, Vatican Media pode estabelecer uma conexão via satélite para encaminhar o sinal para todos os continentes.

Definitivamente, terá sido necessário esperar até o século XX, especialmente sob Pio XI (1922-1939) com a criação da Rádio Vaticano, e sob João XXIII (1958-1963), e com o trabalho de religiosos que foram praticantes-teóricos dos mídia, da imprensa e do audiovisual como Emile Gabel (1971), Raymond Pichard (1913-1992) e Pierre Babin (1986, por ex.), nomeadamente, para que a Igreja Católica revisse a sua opinião sobre a imprensa escrita e os audiovisuais e para que ela se mostrasse aberta, inovadora e atenta relativamente aos mesmos. De fato, ela avalia melhor, 
para a difusão da sua própria mensagem, aquilo que ela pode obter a partir desses novos modos de transmissão e difusão. Ela reconhece gradualmente a existência de uma opinião pública autónoma (DAGENAIS, 1996), incluindo no seu próprio seio, assim como o seu papel de contrapoder necessário ao equilíbrio da sociedade democrática ${ }^{18}$. Os textos oficiais da Igreja Católica que tratam do "apostolado da imprensa" marcam uma evolução significativa e a etapa decisiva, a este respeito, foi o Concílio Vaticano II, um momento crucial e de tensão para a Igreja que, "sem quebrar as amarras com a sua grande tradição, como o temia uma minoria de bispos conservadores, se junta finalmente ao mundo moderno" (TINCQ e DÉFOIS 1997, p.110) e, através da qual ela adota uma surpreendente conversão discursiva (DOUYĖRE, 2018).

\section{A Igreja confrontada com os media modernos}

Na sua utilização dos meios de comunicação, a Igreja Católica tem demonstrado durante séculos uma dupla atitude: às vezes aceita-os e compromete-se com eles, outras vezes mostrase relutante em relação a eles (PINTO DE OLIVEIRA, 1968). Em várias ocasiões, razões teológicas e/ou pastorais serviram para apoiar os seus pontos de vista. Assim, quando a moralidade e a doutrina pareciam ser ameaçadas pelos meios de comunicação, estes eram então relegados ao lugar de instrumentos perigosos para a fé e, portanto, inadmissíveis. Por outro lado, quando eram usados como instrumentos de fé e evangelização, pelas publicações, eles eram bem recebidos e a sua prática era encorajada. De fato, a instituição católica sempre soube tirar partido dos dispositivos de produção semiótica mais relevantes, oscilando entre reticência, resistência e apropriação (DOUYĖRE, 2015). Aliás, Dominique Wolton (2000) sublinha bem que "na longa história da comunicação, a Igreja tem estado desde há um século sempre presente seja com a rádio, seja com a televisão e o cinema ${ }^{19 " .}$

\section{A instituição do Vaticano e a comunicação digital}

Assim como ela se apropriou dos meios de comunicação de massa durante o século XX, a instituição do Vaticano apropria-se da comunicação digital (sites, redes sociais, aplicações móveis). Uma importante novidade no panorama das comunicações sociais do Vaticano foi, em 2011, o nascimento do portal News.va, gerido e patrocinado pelo Pontifício Conselho para as

\footnotetext{
18 H. Tincq e G. Défois, Op. Cit., p. 109.

${ }^{19} \mathrm{D}$. Wolton, « L'Eglise face à la révolution de la communication et à la construction de l'Europe », in Médias et religion en miroir (dir. P. Bréchon et J-P. Willaime), PUF, Paris, 2000, p. 281. 
Comunicações Sociais. Esta criação constitui certamente uma das primeiras novidades da era digital no Vaticano (SCACCIANTE, 2015). A plataforma, sem uma verdadeira linha editorial, constituía um "agregador de notícias" relativas à Sé Apostólica e especialmente sobre a vida do Sumo Pontífice, emanando dos vários mídia do Vaticano. A aplicação para tablet e smartphone The Pope app estava vinculada a esse site agregador e permitia acompanhar os eventos ao vivo e receber as suas notificações. Esses dois dispositivos também davam acesso às fotografias e vídeos do Papa, aos textos completos das homilias, ao calendário de eventos e aos links de todos os mídia do Vaticano.

Paralelamente, o site da Rádio Vaticana constituía uma fonte pontual para os eventos relacionados com a Sé Apostólica e o papa, embora a falta de apelo de programas em direto tenha sido frequentemente criticada, bem como a falta de programas noutras línguas além do italiano (SCACCIANTE, 2015). Por seu lado, o site do Centro Televisivo do Vaticano (CTV) tinha como objetivo informar e documentar as atividades do papa principalmente. Esses dois últimos sites desapareceram após março de 2018, como resultado das mudanças feitas no aparelho comunicacional dos media do Vaticano. O site do Osservatore Romano, ainda existente hoje (www.osservatoreromano.va) encerra uma dimensão universal. 0 discurso do encontro entre fé e razão, mas também sobre a "amizade entre homens e mulheres hoje" aparecem como as linhas diretrizes do jornal. A plataforma inclui todos os textos e documentos pontifícios da Sé Apostólica, em italiano, bem como na língua em que foram falados ou escritos, seguindo, por meio de uma informação completa e precisa, a vida internacional, os debates culturais, a vida da Igreja Católica em cada continente; é dada uma especial atenção ao ecumenismo e ao diálogo inter-religioso.

\section{Redes Sociais Digitais e Aplicações Móveis}

O grande passo de abertura nas redes sociais digitais foi o lançamento da conta do papa no Twitter @Pontifex a 12 de dezembro de 2012. A inscrição no Instagram data de 2016, com a criação da conta Franciscus para o Papa. 10\% dos utilizadores do Twitter seguem o papa em 9 idiomas dominantes (cada conta para uma língua respetiva): espanhol, inglês, francês, italiano, português, alemão, árabe, polonês e latim ou seja 40 milhões de assinantes (16,3 anglófonos, 15,8 hispanófonos, 4.83 italófonos, 3.51 lusófonos e 1.09 francófonos). O Instagram continua a ser a plataforma com maior sucesso, pois 32\% dos seus utilizadores, isto é 5,2 milhões de assinantes, seguem a conta do papa, uma conta universal e única, referenciando os discursos em 6 línguas simultaneamente: espanhol, português, inglês, italiano, francês e alemão (ANZELMO, 2018b). 
Com o nascimento do novo portal Vatican News em 2018, uma página de Facebook sob o mesmo nome foi criada e aplicação WhatsApp é agora usada como um recurso de partilha dos conteúdos no novo portal.

Três aplicações móveis ainda existiam há alguns meses: Vatican.va, Vatican Radio e The pope app. Vatican.va constituía a aplicação do site oficial do Vaticano desde 19 de dezembro de 2014. Desde a reforma dos mídia, a aplicação Vaticano News suplantou os três aplicativos móveis, esta última constitui a aplicação do novo portal.

De acordo com Dario Edoardo Viganò ${ }^{20}$, o objetivo é compreender, no que respeita ao processo de reforma dos mídia do Vaticano, quais são as temáticas que satisfazem o utilizador, porque o novo objetivo tende a colocá-lo no centro como produtor dos percursos tomados no seio das tecnologias. Se o objetivo é oferecer um portal único capaz de produzir informações multimídia, trata-se igualmente de refletir uma mudança de mentalidade. Essa "mudança" consiste em "ir além da certeza que a instituição tem de ser ouvida, para garantir em primeiro lugar que 0 público esteja pronto para receber seus discursos"; a promessa ${ }^{21}$, portanto, tende a concentrar-se nas expectativas e nas necessidades do público em relação às expectativas e necessidades institucionais.

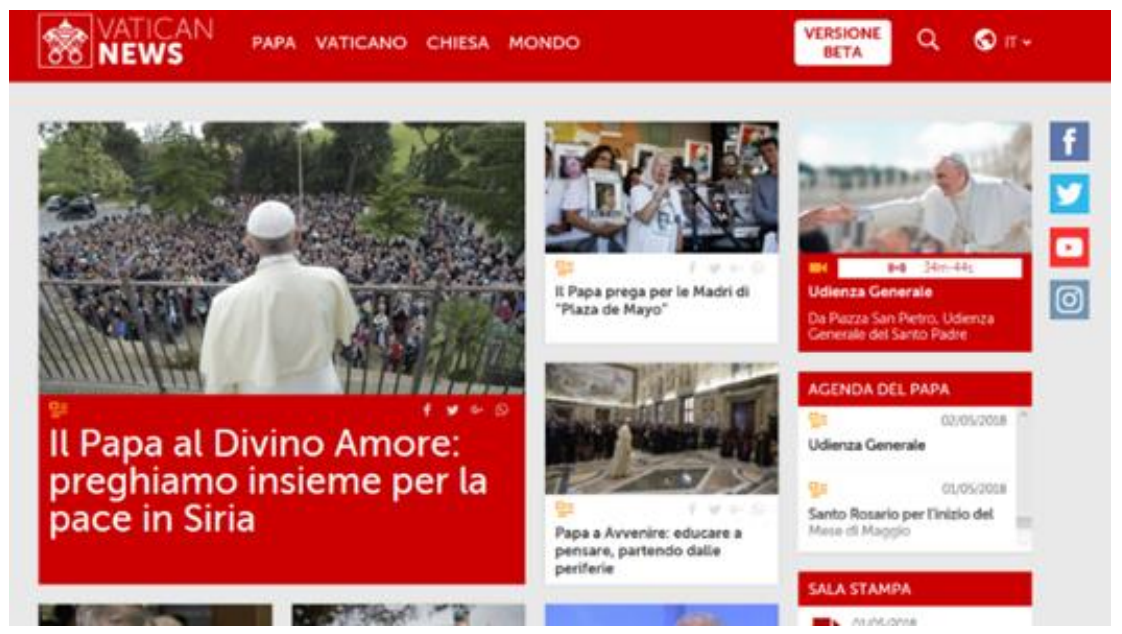

Figura 1 - Captura de écran Fonte: Vatican.news, 2019.

\footnotetext{
${ }^{20}$ Durante a sua conferência para o dia do estudo Forme di vita e radical mediation : persone, ambienti mediali, forme d'esperienza nell'era digitale du 11 mai 2017 na universidade LUMSA (Libera Università Maria SS. Assunta), Rome. ${ }^{21}$ No sentido de Jeanneret (2014, p. 66-67), "designa a maneira como os atores da comunicação intervêm para esclarecer o significado e os propósitos do próprio processo de comunicação e para declarar a sua própria maneira de se envolver nele".
} 
O ano de 2017 caracteriza-se como um ano de ponto de viragem no processo de reforma dos media do Vaticano lançado para alcançar a integração dos órgãos de comunicação tradicionalmente distintos, de acordo com as indicações contidas na Carta Apostólica do Motu Proprio assinada pelo Papa Francisco a 27 de junho de 2015. Esta reforma constitui o ato fundador de um órgão institucional inédito: a Secretaria para a Comunicação (PEVERINI, 2017) ${ }^{22}$. 0 aspeto decisivo é materializado na transição para uma forma mediática concebida para comunicar do interior para o exterior e acabar com a justaposição mediática (cada meio informava o público de forma independente) e coordenar todas as atividades de informação geradas anteriormente de maneira distinta. Este portal digital, nascido oficialmente em janeiro de 2018 com o nome de Vatican.news, tem como objetivo unificar as informações do Vaticano repensando o conteúdo, a produção e a distribuição das notícias de acordo com as mudanças específicas do contexto digital.

\section{Comunicação institucional do Vaticano e "jornalismo de influência"}

Os media religiosos também aparecem igualmente como uma maneira de contrariar a agenda mediática, bastante crítica relativamente a eles, de informar e de juntar comunidades religiosas, internacionalizadas e mundializadas (DOUYĖRE, 2017).

O investigador brasileiro Francisco Sant'Anna (2007) desenvolveu um interessante estudo de fontes jornalísticas que criam os seus próprios mídia, ele denomina-os de "mídia de fontes". Sant'Anna estudou a forma como algumas organizações gerem os seus próprios meios adotando técnicas jornalísticas: estações de rádio e de televisão, jornais, revistas, portais Web, etc. Ele procedeu à identificação de um processo de profissionalização das fontes, em que as organizações não-mediáticas começaram a produzir conteúdo informativo, notícias, para assegurar a transmissão das suas informações no espaço público. Trata-se de um fenómeno que ele denomina também de "jornalismo de fontes" ou "de influência" no sentido de "difusor do jornalismo corporativo" (SANT'ANNA, 2006).

Assim, a imprensa, tradicionalmente considerada como um ator externo aos factos, começa a perder a totalidade do domínio do campo da informação. 0 público recebe mais informações recolhidas, selecionadas, manipuladas por uma linha editorial, filtradas e divulgadas por organizações, movimentos sociais ou empresas detentoras de interesses corporativos. Esses novos media também poderiam ser chamados de Mídia Corporativos, visando menos a transmissão de informações "intra corporis", e procurando principalmente ocupar a agenda

${ }^{22}$ Rebaptizado « Dicastério para a Comunicação » a 26 de junho de 2018. 
mediática através de um ponto de vista setorial sobre fatos gerais. Sant'Anna afirma que esses novos "mídia" procuram assim intervir no processo de produção de notícias (newsmaking) e na formação da opinião pública, tendo em conta a existência de uma poderosa imprensa comercial e de um sistema público extremamente precário ${ }^{23}$. Segundo ele, o fenómeno conduziu, de facto, à "emergência de um tipo de mídia e de jornalistas, ligados aos serviços de imprensa das organizações sociais, das empresas e dos setores governamentais", que ele também chama de jornalismo de influência (SANT'ANNA, 2006b).

Poderíamos pensar em designar toda a informação disseminada por esses mídias como um outro modo de prática jornalística, chamando-a de Jornalismo das Fontes [...]. Estas considerações preliminares permitem-nos ousar pensar no surgimento de um novo modelo de jornalismo e, consequentemente, um novo segmento profissional, que é o jornalismo de influência. (SANT'ANNA, 2006a, p. 3-4).

Os Mídia de Fontes são desenvolvidos nos diferentes setores da sociedade. $\mathrm{O}$ autor alarga o seu ponto de vista também ao campo religioso:

No setor religioso, o espiritismo tem um canal via satélite. A Igreja Católica opera uma rede de estações de rádio espalhadas por todo o país e atua na televisão UHF. A Igreja Universal do Reino de Deus, de linhagem pentecostal, é a proprietária de uma rede nacional de TV aberta, opera no seio de várias rádios e tem a maior circulação semanal do país. A Folha Universal acusa a impressão de 1.673 .000 cópias por edição. (SANT’ANNA, 2006a, p. 5).

O que ele afirma é que "na falta de uma intervenção bem-sucedida nos mídia tradicionais, o papel estratégico dos mídia de fontes cresce cada vez mais" (SANT'ANNA, 2006a, p. 5). Segundo ele, esse cenário (no caso da especificidade brasileira que ele analisa) reside no fato de que as organizações não se limitam a simplesmente a tentar intervir na agenda dos mídia tradicionais (que não se limitam a atuar como fontes de informação), mas estão prontas para difundir, elas próprias, diretamente para o público, as informações, constituindo para isso os seus próprios meios de comunicação: os "mídia das fontes". Trata-se de media assegurados e administrados por atores sociais (principalmente várias organizações não-governamentais) jornais de grande circulação, estações de rádio, televisão, ou mesmo programas especiais - cuja ação informativa visa influenciar o conteúdo da agenda mediática apresentada à opinião pública. Esses atores sociais agem com seus próprios critérios editoriais para definir seus parâmetros em

23 Nesta análise, Sant'Anna (2006a, p. 4) afirma que é importante manter uma visão geral dos conceitos, especialmente o sentido de corporativo: "aqui, usamos o conceito francês segundo o qual a diversidade dos corporativismos é proporcional à diversidade de instituições interessadas na regulação política e social. [...] E que pode ser a base de uma renovação do contrato social". 
termos de critérios de interesse mediático e para selecionar os assuntos que serão divulgados, bem como o seu enquadramento (framing). Às vezes, esses critérios divergem daqueles usados pelos grandes media, proporcionando assim uma maior diversidade de informações na esfera pública (id., 25). Ele conclui que:

[...] este fenómeno é uma tentativa de garantir um quadro informativo e ideológico dentro da sociedade, uma nova proposta para estabelecer a agenda contra a norma mercantilizada, ou mesmo estéril em relação a certos assuntos, adotada pelo newsmaking da imprensa tradicional. (id., p. 26).

A existência de mecanismos de disseminação de ideias, de valores, de mensagens e de conceitos através dos meios de comunicação de massa distintos dos tradicionais deve ser vista como uma busca por um espaço grande ou pequeno, hegemónico ou não na esfera pública, de um lugar ao sol na sociedade contemporânea. Neste "conflito" mediático, a comunicação apresenta-se como um armamento essencial.

Ora, o caso da apropriação e uso dos mídia pela Igreja Católica pode inscrever-se, em nossa opinião, nesta perspectiva defendida por Sant'Anna. Manter uma visibilidade pública é o objetivo principal, uma vez que a Igreja Católica está ciente de que, para interferir no espaço público, é preciso "deter" a agenda mediática. Ela apropriou-se dos meios de comunicação - mídia corporativos - que lhe permitem assim atingir a opinião pública - por meio de informações recolhidas, selecionadas, editadas, filtradas e divulgadas de acordo com os interesses corporativos dos quais a Igreja Católica é detentora. Isso permite-Ihe assumir um papel semelhante aos atores políticos (SANT'ANNA, 2006, p. 3). 0 conjunto da informação divulgada por estes meios apresenta uma modalidade diferente para a prática jornalística - uma dimensão da estratégia de comunicação institucional cujo objetivo é influenciar a opinião pública - podendo ser chamada de Jornalismo de Influência (SANT'ANNA, 2006, p. 4). Esse fenómeno situa-se na fronteira entre o campo do jornalismo (a introdução neste campo de técnicas e valores comuns ao jornalismo praticado nas redações também contribuiu para o seu surgimento) e o campo da comunicação organizacional e das relações públicas. Além disso, a estratégia discursiva não se limita à produção da sua própria fala, mas influencia o campo jornalístico através dos pseudoeventos organizados para atrair a atenção da imprensa e aparecer na agenda, o que constitui uma tentativa de garantir um quadro ideológico de referência na sociedade. A função estratégica dos "mídia de fontes" aumenta na medida da impossibilidade de interferir satisfatoriamente nos meios de comunicação tradicionais, (SANT'ANNA, 2006, p. 11). Parece ser, efetivamente, esse o caso da Igreja Católica no contexto digital. 


\section{As mudanças no posicionamento discursivo na era digital: os valores veiculados na Web}

De acordo com Franciscu Sedda (2017, p. 64), "a Igreja Católica dificilmente pode inscrever a sua ação, mesmo a menor e desinteressada, fora de um horizonte de propagação dos seus valores", razão pela qual, nos parece fundamental estudá-los, especialmente no seio da comunicação digital. Como evocado pelo papa (Papa Francisco, 2017), as redes sociais como 0 Twitter permitem que ele se aproxime do público e novas modalidades de comunicação, como a proximidade, são permitidas por esses dispositivos. Se, como menciona David Douyère $(2015, p$. 229), a instituição católica "descobre os meios de comunicação, ao praticá-los ", isso implica um período de adaptação ao longo do qual ela teve de se familiarizar com eles. É por isso que a reforma e a institucionalização do Dicastério para a Comunicação servem um novo propósito: apropriar-se das tecnologias informatizadas de forma pertinente para mobilizar um público massivo em torno da fé católica. Com efeito, a "nova evangelização digital24" parece trazer duas forças: atenuar, por um lado, o enfraquecimento da fé cristã na Europa, "a incessante difusão da indiferença religiosa, a secularização e o ateísmo" (Bento XVI, 2010) e, por outro, permitir a evangelização mundial, manter a fé e alimentá-la em países que já têm um forte fervor católico, tocando-os, graças à Internet. Esta última parece facilitar a mediatização da matriz axiológica do Vaticano.

Para dar conta dos processos comunicacionais que se inserem no jornalismo de influência, nós concentrámo-nos na difusão dos valores de compromisso. Apenas evocaremos aqui um desses aspetos axiológicos: 0 da causa feminina.

O suplemento mensal Donne, Chiesa, Mondo publicado desde 2012 pelo Osservatore Romano online e offline é dedicado às mulheres. Uma atenção especial é dada à sua relação com a Igreja Cristã e o objetivo é aprofundar o conhecimento do seu papel, enfrentando temas controversos como a questão do seu diaconato e da sua ordenação. A linha editorial tende a mostrar como "esse mundo feminino - ainda desconhecido, embora próximo de nós - tem a ensinar-nos" (GALEOTTI, 2017) e constitui a tentativa de conduzir as mulheres para uma maior valorização.

\footnotetext{
24 Termo de David Douyère (2015) explicando que na corrente do "e-vangelismo" (evangelismo digital), por exemplo, aparece um mandato religioso de evangelização que requer o uso de ferramentas digitais. 


\section{DONNE CHIESA MONDO}

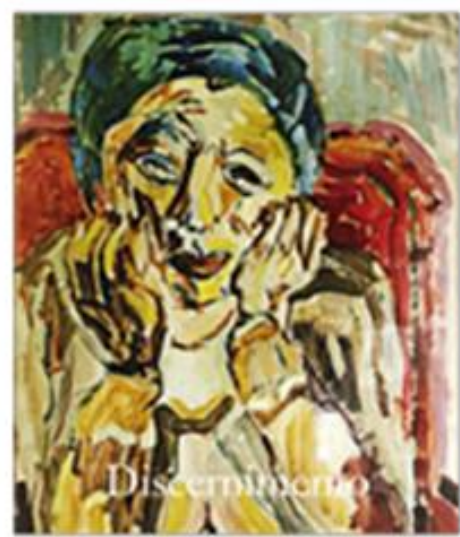

\section{DONNE CHIESA MONDO}

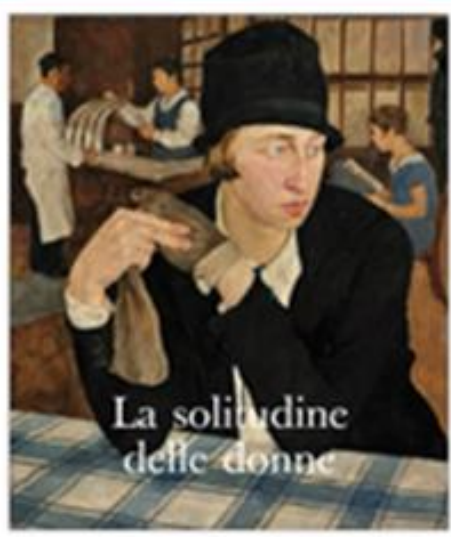

Figura 2 - Exemplares do suplemento Donne Chiesa Mondo

Fonte: Capturas de écran do site Osservatore Romano http://www.osservatoreromano.va/fr/section/femmes-eglise-monde). 2019

Vários artigos biográficos são dedicados a figuras femininas conhecidas pela tradição cristã (KNOX, 2017 e LOSSKY, 2017) para as mostrar como exemplo. Esses conteúdos evocam as suas dificuldades para serem ouvidas no contexto histórico da época e sublinham a sua luta para enfrentar questões teológicas como a ordenação e o diaconato. A questão do género é abordada pelo estudo de passagens evangélicas como a de "Jesus e a Samaritana" (DELGADO, 2017), em que a autora defende uma abordagem resolutamente "feminista" e se reapropria do texto bíblico para defender um ponto de vista filosófico em favor das mulheres.

Este suplemento constitui, portanto, um dispositivo mediático para disseminar uma teologia feminista "inspirada por um desejo de libertação e tendo plenamente conta a experiência das mulheres" (TORRELL, 2008). Na verdade, permitindo a descoberta da história das mulheres, estes conteúdos valorizam personalidades que desempenharam um papel importante na Igreja e na sociedade, dando as feministas "o exemplo das lutas das suas irmãs do passado" (TORRELL, 2008). Da mesma forma, trata-se de evocar, de questionar os lugares comuns depreciadores da mulheres veiculados pela tradição cristã como o artigo Bugliani Knox (KNOX, 2017) evocando 0 desejo de defender, de testemunhar e difundir a fé católica recusando "a ideia de que as mulheres eram apenas criaturas fracas e volúveis, destinadas a casamentos ou ordens monásticas".

Essa difusão contribui para forjar uma axiologia que tende à abertura e ao diálogo entre homens e mulheres. 
Os discursos do papa católico 25 transmitidos pelas reportagens do CTV reforçam essa luta feminista denunciando em particular o machismo e a instrumentalização do corpo da mulher. Outros discursos do papa ${ }^{26}$, mais comprometidos, ressaltam o direito das mulheres a serem inseridas em todos os campos (profissionais ou não) e a eventual necessidade de estabelecer dispositivos legais para afirmar esse direito.

Esses conteúdos esforçam-se para valorizar as mulheres, na medida em que ela é igual ao homem no prolongamento do pensamento cristão sobre a igualdade dos sexos, em que homens e mulheres são considerados iguais como pessoas humanas ${ }^{27}$. Também é interessante notar que o título "Mulheres, Igreja e Sociedade" no site da Rádio Vaticana faz eco do suplemento Donne Chiesa Mondo propondo, desta vez, uma multitude de conteúdos para a valorização das mulheres na sociedade, tais como no domínio desportivo (MUANDO BUABUALO, 2017a) e tecnológico (MUANDO BUABUALO, 2017b).

Ao mostrar um ethos fundado no diálogo com a sociedade sobre questões femininas, a instituição do Vaticano está tomar parte do recente debate sobre as agressões e o assédio sexuais denunciado por milhares de mulheres, nomeadamente no contexto do caso Harvey Weinstein (KANTOR E TWOHEY, 2017). De fato, as palavras do Cardeal Gianfranco Ravasi, através do site da Rádio Vaticana (2017), denunciam o uso do poder e da superioridade masculina. Tal ato impulsiona a expressão da ética do Vaticano num debate público de grande amplitude que favorece a disseminação da sua posição católica sobre o género, alinhando-se assim, com a reflexão contemporânea sobre 0 assédio. Além disso, o processo parece semelhante ao tema anterior: o site da Rádio Vaticana gera conteúdo convocando o ponto de vista de profissionais tal como a de uma conselheira familiar lembrando a importância da "educação sexual nas escolas para libertar a criança e ajudá-la a expressar suas emoções" (Allaire).

O ethos constitui o plano da expressão da ética e compõe, assim, o conjunto das formas sensiveis e observáveis no comportamento do ator (FONTANILLE, 2008). Assim, podemos considerar que a mediatização desse comportamento comprometido com a causa feminina contribui para a construção axiológica da abertura e do diálogo e, procura, simultaneamente, transformar o estereótipo da misoginia alimentada pela cultura de massa, o que se reveste de

\footnotetext{
25 Site de YouTube [on-line] « Papa Francesco: la donna non è una replica dell'uomo », publicado a 24/04/2015, (acesso em 23/10/2017]. Disponível em: https://www.youtube.com/watch?v=TL9HRzEt3uo.

${ }^{26}$ Site de YouTube [on-line] « II Papa: tutelare le donne nell'educazione alla fraternità » publicado a 9/06/2017, [acesso em 23/10/2017]. Disponível em: https://www.youtube.com/watch?v=XRhQ_NYGjAw.

27 Segundo o Catecismo da Igreja católica, "III. Homem e mulher ele os criou", "Igualdade e diferença desejada por Deus". Disponível em: http://www.vatican.va/archive/FRA0013/_INDEX.HTM. Acesso em 08/05/2018.
} 
especial relevância no contexto atual, já que a mulher de trinta anos representa o perfil típico dos mídia do Vaticano ${ }^{28}$.

Essa transformação parece realizar-se, segundo os trabalhos de Sant'Anna, pelos discursos difundidos pelos meios de comunicação do Vaticano, que tendem a ocupar a agenda mediática (como vimos, ao inserir nos debates como o assédio sexual, a paridade homem-mulher) ao difundir o ponto de vista eclesial católico. Esses atores dos media do Vaticano agem com seus próprios critérios editoriais para realizar um enquadramento (framing) em relação direta com a agenda mediática.

À luz das observações - esclarecidas pelo Papa Francisco (2017), - de Dominique Wolton, assistimos a uma simulação do diálogo entre tradição e modernidade. A estratégia comunicacional atual adota valores de aparência de diálogo, de inclusão destacados por Paolo Peverini (2017) (em vários níveis: palavra de profissionais convocada (cf. Catherine Bonnet), importância dada às problemáticas femininas dominadas pela da humildade.

Além disso, também se trata de assumir um papel político apoiado por modalidades jornalísticas diferentes, realizando uma estratégia de comunicação institucional com a ajuda de discursos que difundam uma militância política hostil à liberdade de interrupção voluntária da gravidez (ver fig. 3), a eutanásia ou ainda a pena de morte.

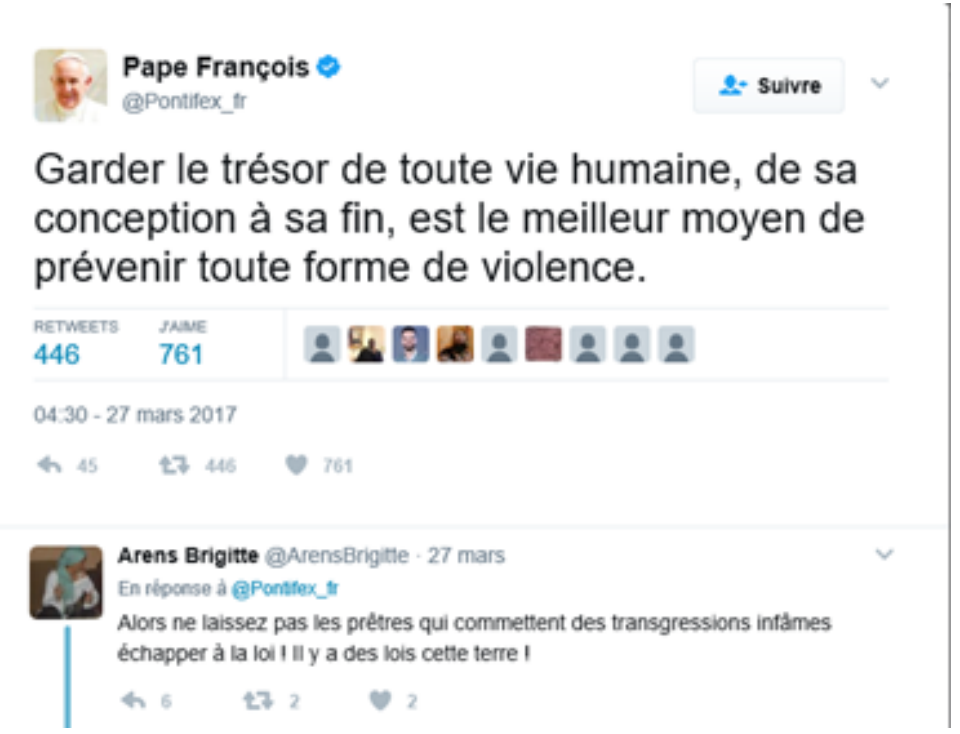

Figura 3 - Militantismo político contra o aborto na conta do Twitter do Papa Fonte: Twitter, 2019.

\footnotetext{
28 De acordo com Paolo Peverini, consultor da Secretaria para a Comunicação do Vaticano, durante uma entrevista que realizámos em Roma em 9 de novembro de 2017. 


\section{Projeções estratégicas das lógicas mediáticas e tecnológicas atuais}

Depois de termos visto que os atores dos mídia do Vaticano difundem, entre outras coisas, discursos feministas e parecem realizar um "jornalismo de influência", privilegiando o ponto de vista segundo o qual o processo de mediatização é pensado como sistema, vamos analisar este último, uma vez que a mediatização dos mass media - isto é, a produção intencional de difusão em larga escala - é o objeto por excelência de uma análise semi-comunicacional (MITROPOULOU, 2015). Ao examinar esse processo, será necessário ver como os dispositivos mass media usados na comunicação do Vaticano podem reforçar esse jornalismo de influência.

Para começar, partimos da constatação de que o conjunto dos conteúdos difundidos por cada médium do Vaticano se encontra in fine na Internet (através dos sites de web dos media) e pode então ser publicado (às vezes de forma idêntica e às vezes de uma maneira diferente) em plataformas das redes sociais (cada médium é inscrito no Twitter, Facebook, YouTube). Tal circuito de mediático é regido por uma lógica de passagem (AMAR, 2016) no sentido em que os discursos são injetados em "locais de passagem potenciais" a serem recebidos por uma massa de recetores.

Por exemplo, o valor do ecumenismo expresso e destacado pelo discurso do artigo italiano «ll Papa ha ricevuto il grande Imam di Al-Azan» (o papa recebeu o grande Imã de Al-Azhar) (fig.3) publicado no portal Vatican News, encontra-se introduzido no Instagram por um post (fig. 4).

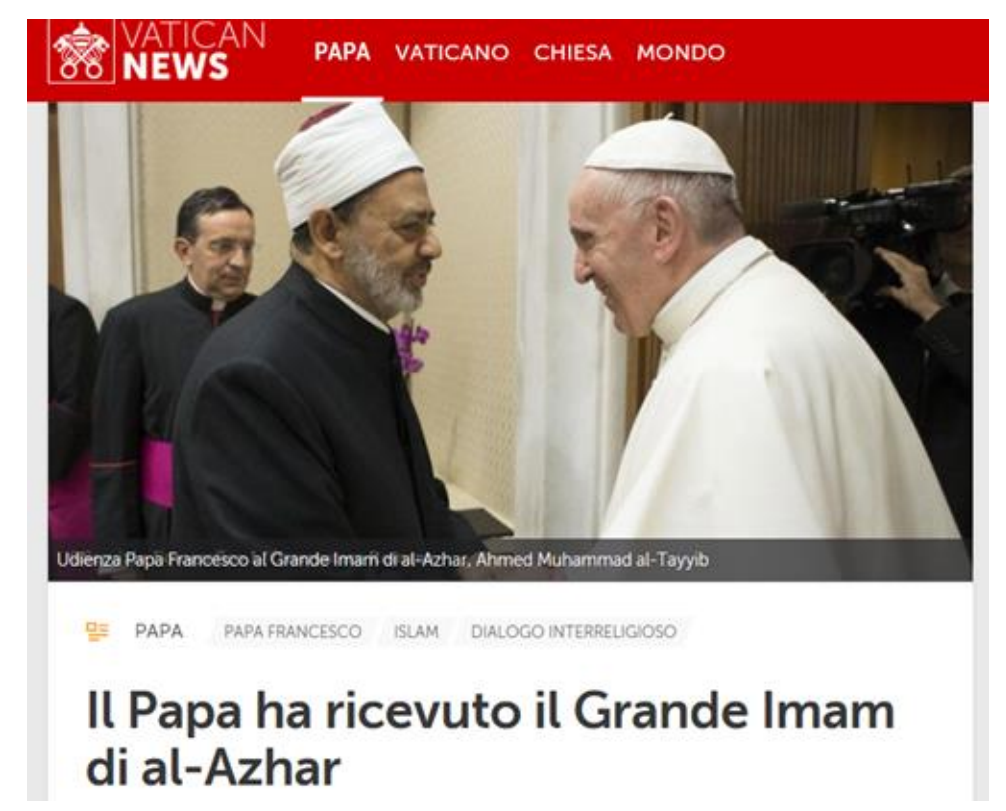

Figure 4 - Artigo sobre Vatican News Fonte: Vatican News, 2019. 

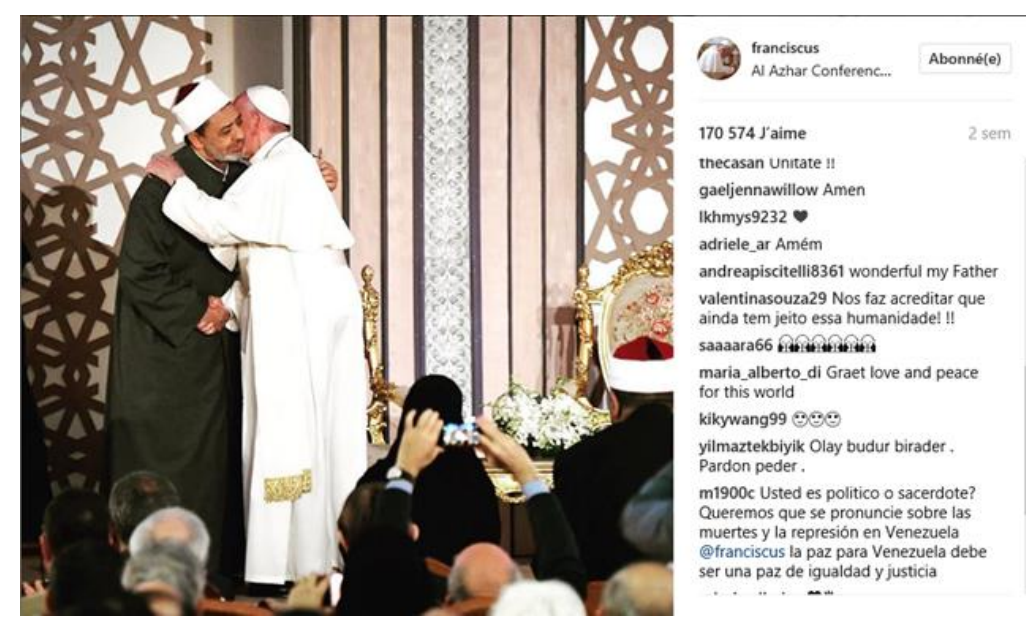

Figura 5 - Post relativo ao discurso do artigo fig. 3 reformulado com a legenda "Juntos vamos afirmar a incompatibilidade entre violência e fé, entre crer e odiar", 2019.

Esta lógica também diz respeito ao suplemento Donne Chiesa Mondo que, em Itália, é vendido em quiosque em lote com a versão semanal do Osservatore Romano gratuitamente. Por outras palavras, o suporte em questão "alcança" o leitor habitual do jornal "tradicional", que obtém, na compra, este suplemento que propõe conteúdos teológicos feministas. 0 processo da redistribuição informacional é, portanto, não apenas digital, mesmo que não se possa negligenciar a contribuição do Twitter para a mediatização (ver abaixo o tweet Lucetta Scaraffia, líder de Donne Chiesa Mondo comunicando o sumário da edição de fevereiro de 2017 usando a hashtag \#DonneChiesaMondo e do Osservatore Romano):

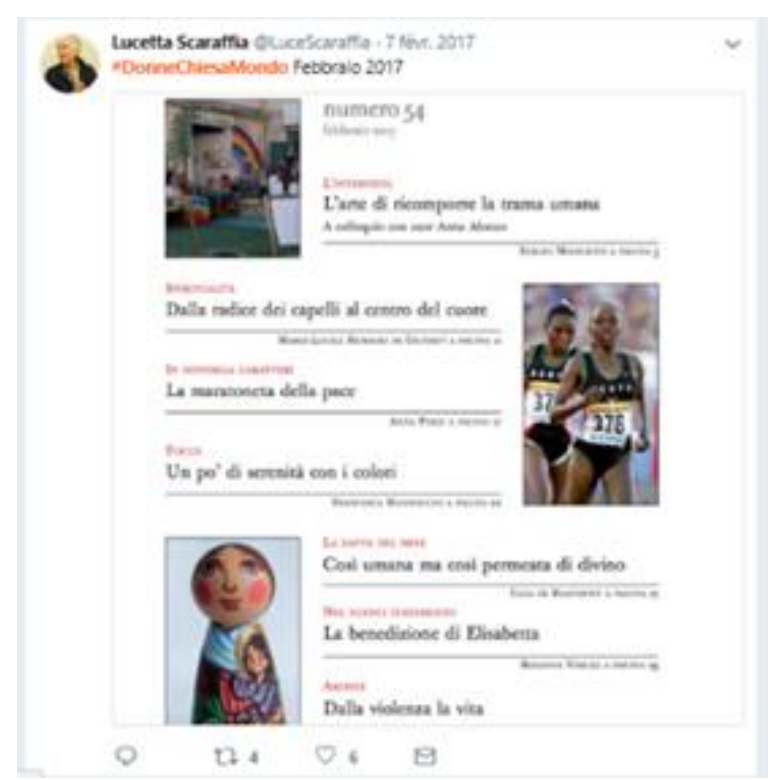

Figura 6: Tweet de Lucetta Scaraffia, dirigente do supplemento Donne Chiesa Mondo Fonte: (captura de écran página da hashtag \#DonneChiesaMondo https://twitter.com/search?src=typd\&q=\%23donnechiesamondo), 2019. 


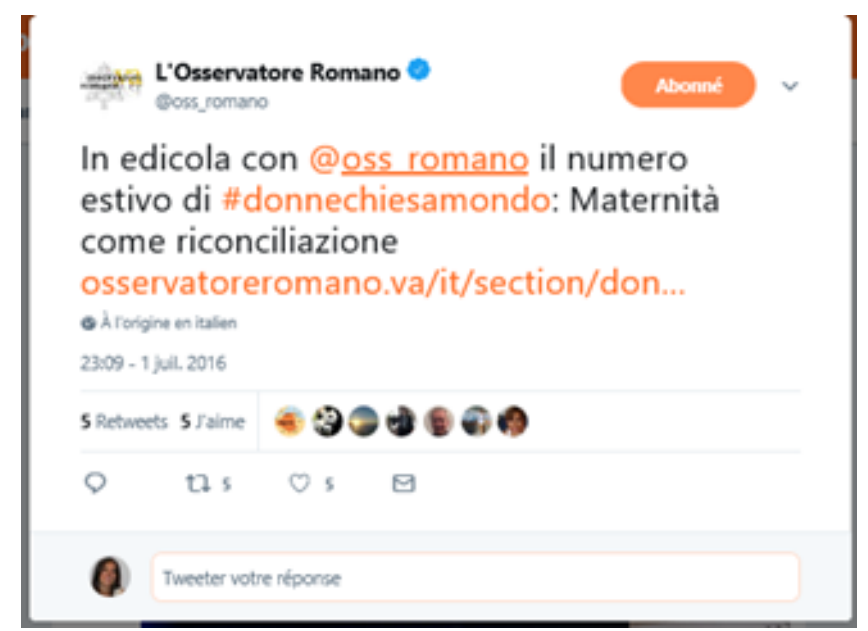

Figura 7 - Tweet do Osservatore Romano para promover o supplemento Donne Chiesa Mondo Fonte: (captura de écran página da hashtag \#DonneChiesaMondo https://twitter.com/search?src=typd\&q=\%23donnechiesamondo), 2019.

O tweet ${ }^{29}$ deste papa para as mulheres (ver abaixo) ilustra a isotopia da inclusão, a mensagem é retweetada 1800 vezes, gostada por 5300 tweeters e gerou 224 respostas.

\section{Papa Francesco 0 @Pontifex_it - 25 nov. 2016}

Quante donne sopraffatte dal peso della vita e dal dramma della violenza! II Signore le vuole libere e in piena dignita.

(1) À rorigine en italien

$1,8 \mathrm{k}$

$5,3 \mathrm{k}$

Figura 8 - Tweet valorisando as mulheres

Fonte: (captura écran da conta Twitter italiana do papa https://twitter.com/Pontifex_it), 2019.

Esses discursos abrangendo valores de inclusão mostram, pelo seu modo de circulação, efeitos de redundância discursiva quando são difundidos em diversas plataformas. 0 discurso papal publicado no YouTube através do canal CTV (Figura 9) é originalmente de uma reportagem do CTV e é finalmente retransmitido via Twitter (Figura 10). Tal processo de repetição pode recordar a noção de "pré-propaganda" evidenciada por Ellul ([1962] 2008, p.74), visando, na sua visão, criar um reflexo condicionado por parte da massa recetora da mensagem. Esse reflexo condicionado poderia ser, nesse caso, da partilha, retweet ou do like nas redes sociais, participando, assim, diretamente no processo de propagação discursiva ${ }^{30}$.

29 Traduzimos aqui o discurso do tweet: "quantas mulheres foram esmagadas pelo peso da vida e pelo drama da violência! O Senhor as quer livres e cheias de dignidade".

30 Ellul (2008, p. 74) define propaganda como "o conjunto de métodos utilizados por um grupo organizado para participar ativa ou passivamente da sua ação, uma massa de indivíduos psicologicamente unificados por manipulações psicológicas e enquadradas numa organização". 


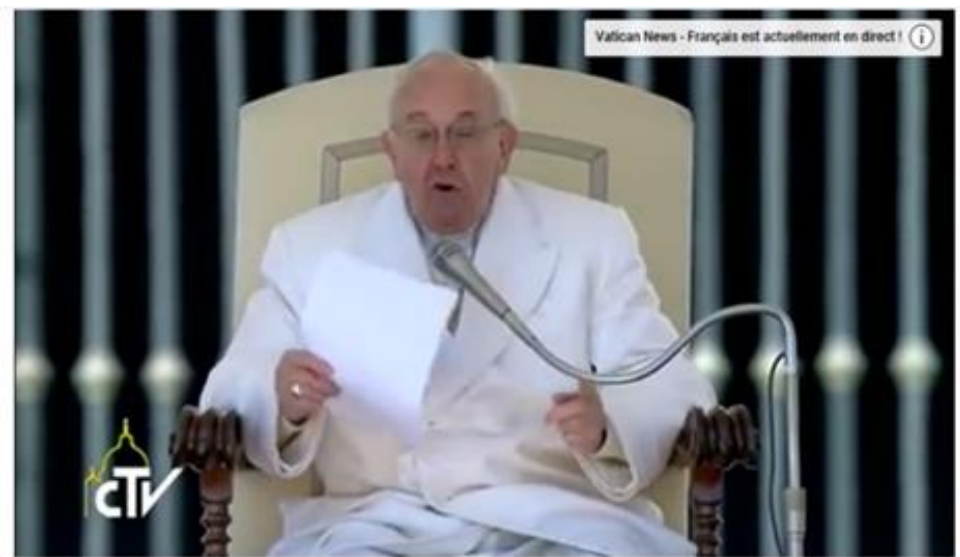

Pape François : le christianisme r'est pas une idéologie mais un chemin de foi

438 vues

Figura 9 - Reportagem do CTV no YouTube documentando o discurso do papa

Fonte: (captura de écran do vídeo YouTube https://www.youtube.com/watch?v=\|ISZjcFyoBM), 2019.

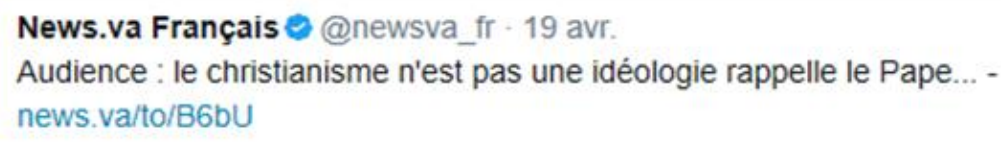

Figura 10 - Tweet da conta News.va (site agregador de notícias.

Fonte: (captura de écran da conta Twitter News.va em francês, fechado depois de março de 2018 no quadro da reforma dos media do Vaticano e a criação da nova conta Vatican News no Twitter), 2019.

\section{Conclusão}

Ao privilegiar uma axiologia fundamentada, como vimos, em valores que evocam abertura e diálogo, os media do Vaticano comunicam inserindo-se num jornalismo de influência. Ao apropriar-se de dispositivos de comunicação de massa, tais como websites e redes sociais digitais, a Sé Apostólica atinge o maior número de indivíduos através de perguntas abertas que interessam tanto o crente quanto o incrédulo (ANZELMO, 2018b), dando a este tipo de jornalismo identificado por Sant'Anna, uma força de mediática significativa, não negligenciável, incluindo uma dimensão tecnológica (partilha, retweet, like) específico das tecnologias informatizadas. Esse valor mediático para os discursos tende a facilitar a sua inserção em debates públicos de larga escala e, assim, intervir na formação da opinião pública.

Este exame da utilização social dos objetos mediáticos e da sua capacidade de moldar as produções culturais permitiu-nos abordar o processo de comunicação que consiste em tornar presente a mensagem católica num espaço público mediaticamente desintermediado, através de 
uma forma de "jornalismo de fonte", ou seja a produção de conteúdo em vez de e no lugar dos mídia, carregando emoção, mensagens, discursos ancorados à atualidade, imagens. A Propaganda renova assim as suas formas.

\section{Referências}

ALLAIRE Delphine. «Face au harcèlement, la nécessaire éducation à l'altérité ». Radio Vatican, 9 nov 2017. Disponível em: <http://fr.radiovaticana.va/news/2017/11/09/face_au_harcèlement,_la_nécessaire_éducation_à_l alterité/1347792>. Acedido em 14 nov 2017.

AMAR, Pierre. Internet : le nouveau presbytère ou comment rassembler des brebis avec des souris, Paris, Perpignan : Artège Lethielleux, 2016, 160 p.

ANONYME. "Harcèlement des femmes : le cardinal Ravasi plaide pour une éducation des plus jeunes ». Radio Vatican, 21 oct 2017. Disponível em: <http://fr.radiovaticana.va/news/2017/10/21/harcèlement_des_femmes_le_cardinal_ravasi_plaide _pour_une_éducation_des_plus_jeunes/1344467>. Acedido em 14 nov 2017.

ANTOINE, Frédéric. Le Grand Malentendu : l'Église a-t-elle perdu la culture et les médias ? Paris : Desclée de Brouwer, 2003, 223 p.

ANTOINE Frédéric, DOUYĖRE David (dir.). « Religions et médias ». In : Revue française des sciences de l'information et de la communication, $n^{\circ} 13$, introduction : " Penser l'entrelacs des religions et des médias », 2018. Disponível em: <https://journals.openedition.org/rfsic/3756>.

ANZELMO Angela. «Les médias du Vatican face aux questions féministe et de pédophilie ». In : Revue française des sciences de l'information et de la communication [On-line], 13 | 2018, 01 juin 2018, 2018a. Disponível em: <http://journals.openedition.org/rfsic/3739> ; <DOI : 10.4000/rfsic.3739>. Acesso em 25 jun 2018.

ANZELMO Angela. «Église catholique et technologies informatisées : interactions médiatiques avec un public de masse » Poitiers, 2018b. Disponível em: <https://hal-univ-poitiers.archivesouvertes.fr/hal-01726665>. Acesso em 21 abr 2018.

BABIN Pierre. L'Ėre de la communication, réflexion chrétienne. Paris : Le Centurion, Ocic, 1986. $228 p$.

BARAGLI Enrico. Comunicazione, comunione e Chiesa. Rome: Studio Romano della comunicazione sociale, 1973.

BENOÎT XVI. « Motu proprio Ubicumque et semper pour l'institutionnalisation du Conseil pontifical pour la promotion de la nouvelle évangélisation », site Vatican. Va, 2010.

Disponível em: <http://w2.vatican.va/content/benedict-xvi/fr/apost_letters/documents/hf_benxvi_apl_20100921_ubicumque-et-semper.html>. Acesso em 12 dez 2017.

BRÉCHON Pierre, WILLAIME Jean-Paul. Médias et religions en miroir. Paris : Puf, 2000, p. 329. 
BROUCKER Jose de. La presse catholique en France : état des lieux et des questions. Paris : Le Centurion, 1992.

BUGLIANI KNOX Francesa. « Lo vidi entrare nel mio cuore e nascondersi lì ». In Donne, Chiesa, Mondo, 60, Vatican, septembre 2017, p. 22-25.

CHARENTENAY Pierre de. Le dilemme du chartreux. Médias et Église. Paris : Desclee de brouwer, 2011, $234 \mathrm{p}$.

DAGENAIS Bernard. « Les médias ont imposé une nouvelle logique à la religion », Communication et organisation, $\mathrm{n}^{\circ} \quad 9, \quad 1996 . \quad$ Disponivel em: <http://journals.openedition.org/communicationorganisation/1840>. Acedido em 6 nov 2017.

DAYAN Daniel. «Présentation du Pape en Voyageur. Télévision, expérience rituelle, dramaturgie politique ». In Terrain, n¹5, 13-28, 1990.

DAYAN Daniel. "The pope in Reunion. Hagiography, Casting and Imaginatio ». In E. Rothenbuhler, M. Coman (dir.), Media Anthropology. London: Sage, 163-176, 2005.

DEBRAY Régis. Introduction à la médiologie. Paris: PUF, 2000, p. 223.

DECRETO INTER MIRIFICA SOBRE OS MEIOS DE COMUNICAÇÃO SOCIAL, Disponível em: $<$ http://www.vatican.va/archive/hist_councils/ii_vatican_council/documents/vatii_decree_19631204_inter-mirifica_po.html>. Acesso em 15 abr 2018.

DELGADO Maria José. « La donna di Samaria e l'ebreo Gesù », Donne, Chiesa, Mondo, 60, Vatican, septembre 2017, p. 29-35.

DÉFOIS Gérad, TINCQ Henry. Les Médias et l"Église, Évangelisation et information: le conflit de deux paroles. Paris : CFPJ, 1997, $156 \mathrm{p}$.

DOUYĖRE David. «Communication et religion chrétienne catholique ». In Cahiers de la Sfsic $n^{\circ} 5$. "Actualité de la recherche ", 17-18, 2010a. Disponível em: $<$ https://www.sfsic.org/index.php/publications-sfsic-300107/les-cahiers-de-la-sfsic >. Acesso em 20 out 2015.

DOUYÈRE David. « La communication sociale : une perspective de l'Église catholique? Jean Devèze et la critique de la notion de "communication sociale»". In Revue internationale de communication sociale et publique, $n^{\circ} 3-4$. Uqam, Montréal, 73-86, 2010b. Disponível em: http://www.revuecsp.uqam.ca/numero/n3-4/pdf/RICSP_Douyere_2010.pdf $>$. Acesso em 20 de out 2015.

DOUYĖRE David. «Communication et religions : quelle place pour les médias confessionnels ? ". Ina global, 2017. Disponível em: <http://www.inaglobal.fr/idees/article/communication-et-religionsquelle-place-pour-les-medias-confessionnels-9747>. Acesso em 5 fev 2018.

DOUYĖRE David. « Les mutations communicationnelles du christianisme catholique au XXe siècle ». in Hermès 1 : 71, 225-235, 2015. Disponível em: <http://documents.irevues.inist.fr/bitstream/handle/2042/58829/Hermes_2015_71-225-235.pdf>. Acesso em 21 mar 2018. 
DOUYÈRE David (dir.). « Le Christianisme en communication(s) », Communication \& Langages, n 189, p. 25-140 (introduction, p. 25-46), 2016.

DOUYĖRE David. Communiquer la doctrine catholique, Textes et conversations durant le concile Vatican II d'après le journal d'Yves Congar, Genève, Labor \& Fides, "Enquêtes », 2018, 252 p.

DUFOUR Stéphane. «Un témoignage sensible, la parole du chrétien selon le pape François ». In Communication \& Langages, 189. 25-46, 2016.

ELLUL Jacques. Propagandes. Paris : Economica, [1962], 2008.

FONTANILLE Jacques. Pratiques sémiotiques. Paris : PUF, 2008, 320 p.

GABEL Émile. L'Enjeu des médias. éd. par Pierre Fertin. Paris : Mame, 1971, 472 p.

GALEOTTI Giulia. «L'editoriale», Donne, Chiesa, Mondo, 62, Vatican, novembre 2017, p. 2.

GOMEZ-MEJIA Gustavo. Les fabriques de soi ? Identité et Industrie sur le web. Paris : MKF, 2016, $152 \mathrm{p}$.

INSTRUÇÃO PASTORAL "COMMUNIO ET PROGRESSIO" SOBRE OS MEIOS DE COMUNICAÇÃO SOCIAL PUBLICADA POR MANDATO DO CONCILIO ECUMÉNICO II DO VATICANO. Disponível em: http://www.vatican.va/roman_curia/pontifical_councils/pccs/documents/rc_pc_pccs_doc_2305197 1_communio_po.html>. Acesso em 15 abr 2018.

JEANNERET Yves. Critique de la trivialité. Les médiations de la communication, enjeu de pouvoir. Paris: Non Standard, 2014, 784 p.

KANTOR Jodi et TWOHEY Megan. « Harvey Weinstein Paid Off Sexual Harassment Accusers for Decades ", The New York Times, 2017. Disponivel em: <http://www.nytimes.com/2017/10/05/us/harvey-weinstein-harassment-allegations.html>. Acesso em 12 dez 2017.

LEVALOIS Christophe. Prendre Soin de l'autre - Une vision Chrétienne de la Communication. Paris : Cerf, 2012, $157 \mathrm{p}$.

LOSSKY Olga. « Un ponte tra oriente e occidente », Donne, Chiesa, Mondo, 62, Vatican, novembre 2017, p. 11-15.

MARCHESSAULT Guy. Médias et foi chrétienne : deux univers à concilier; divergences et convergences. Montréal: Fides, 2002, 187 p.

MENSAGEM DO PAPA PAULO VI PARA $O 1^{\circ}$ DIA MUNDIAL DAS COMUNICAÇÕES SOCIAIS 1967. "Os meios de comunicação social» (Domingo, 7 de Maio de 1967). Disponível em: $<$ https://w2.vatican.va/content/paul-vi/pt/messages/communications/documents/hf_pvi_mes_19670507_i-com-day.html>. Acesso em 15 abr 2018. 
MITROPOULOU Eleni. «Valeurs et sémiotique de la communication médiatée : pour une approche inférentielle et transversale ». In Amir Biglari, Valeurs aux fondements de la sémiotique, Paris : L'Harmattan, 2015, 579-607.

MUANDO BUABUALO Marie José. " Bibiana Steinhaus première femme arbitre principale en Bundesliga ", Radio Vatican, 21 août 2017 [a]. Disponível em: <http://fr.radiovaticana.va/news/2017/08/21/bibiana_steinhaus_première_femme_arbitre_principa le_en_bundesliga/1331966>. Acedido em 14 nov 2017.

MUANDO BUABUALO Marie José. "Thérèse Kirongozi et les femmes engagées dans les technologies ", Radio Vatican, le 30 septembre 2017 [b]. Disponível em: <http://fr.radiovaticana.va/news/2017/09/30/rdc_th\%C3\%A9r\%C3\%A8se_kirongozi_et_les_fem mes_engag\%C3\%A9es_dans_les_technologies/1340001>. Consultado em 14 nov 2017.

PACE Enzo. Religion as communication, God's Talk, Surrey, Burlington: Ashgate, 2011.

PAPE FRANÇOIS. Politique et société. Pape François, rencontres avec Dominique Wolton, Paris : éditions de l'Observatoire, 2017, 403 p.

PEVERINI Paolo. « Francesco e i media vaticani. Un racconto in divenire ». Lorusso Anna Maria, Peverini Paolo, II racconto di Francesco. La comunicazione del papa nell'era della connessione globale. Rome: Luiss University Press, 2017, 200 p.

PINTO DE OLIVEIRA, Carlos Josaphat. Information et Propagande, responsabilités chrétiennes. Paris : Le Cerf, 1968.

PINTO DE OLIVEIRA Carlos Josaphat. Éthique chrétienne et dignité de l'homme. Fribourg : éditions universitaires, 1992.

SANT'ANNA Francisco. « Mídia das fontes: o difusor do jornalismo corporativo », 2006. Disponível em: <http://www.bocc.ubi.pt/pag/santanna-francisco-midia-fontes.pdf>. Acesso em 10 maio 2014.

SANT'ANNA Francisco. Média de source - un nouvel acteur sur la scène journalistique brésilienne. Thèse de doctorat "Information - Communication ». Université de Rennes. France, 2007. Disponível em: <https://www.theses.fr/2007REN1G008 >. Acesso em 10 de maio de 2014.

SCACCIANTE Paola. « La Comunicazione digitale in Vaticano, Case study @Pontifex ». Mémoire de Master. Roma: Libera Università Internazionale degli Studi Sociali Guido Carli, 2015, 57 p.

SEDDA Franciscu. " Imprevidibile Franciscus » dans Lorusso Anna Maria, Peverini Paolo, II racconto di Francesco. La comunicazione del papa nell'era della connessione globale. Rome: Luiss University Press, $200 \mathrm{p}$.

SOUCHIER Emmanuël, JEANNERET Yves, LE MAREC Joëlle. Lire, écrire, récrire : objet, signes et pratiques des médias informatisés. Paris: Bibliothèque Centre Pompidou, coll. « Études et recherche », 2003, $350 p$.

TORRELL Jean-Pierre. La théologie catholique. Paris : Le Cerf, 2088, 161 p. 
VATICAN - FR. Catéchisme de l'Église catholique. " III. Homme et femme il les créa", «Égalité et différence voulues par Dieu $", \quad 2003 . \quad$ Disponível em: http://www.vatican.va/archive/FRA0013/_INDEX.HTM>. Acesso em 8 mai 2018.

VATICAN - IT Archive. «Papa Francesco: la donna non è una replica dell'uomo », Youtube. Disponivel em: <https://www.youtube.com/watch?v=TL9HRzEt3uo>. Acedido em 14 nov 2017.

VATICAN News - Français. « Pape François : le christianisme n'est pas une idéologie mais un chemin de foi ", Youtube, 19 avril 2017. Disponível em: <https://www.youtube.com/watch?v=IISZjcFyoBM>. Acedido em 14 nov 2017.

VATICAN News - Italien. « II Papa ha ricevuto il grande Imam di Al-Azar », 7 novembre 2017. Disponivel em: <https://www.vaticannews.va/it/papa/news/2017-11/il-papa-ha-ricevuto-il-grandeimam-di-al-azhar.html>. Acedido em 14 nov 2017.

VATICAN News - Italiano. « II Papa: tutelare le donne nell'educazione alla fraternità », Youtube, 9 juin 2017. Disponível em: <https://www.youtube.com/watch?v=XRhQ_NYGjAw>. Acedido em 14 nov 2017. 